\title{
ANDROGEN RELEASE AND SYNTHESIS IN VITRO BY HUMAN ADULT ADRENAL GLANDS *
}

\author{
By GEORGE L. COHN ANd PATRICK J. MULROW
}

\author{
(From the Department of Internal Medicine, Yale University School of Medicine, New Haven, \\ Conn., and the Medical Service, Veterans Administration Hospital, \\ West Haven, Conn.)
}

(Submitted for publication June 14, 1962; accepted September 20, 1962)

It is well established that surviving human adrenal slices 1) release corticosteroids into the media; 2) increase their output in response to $\mathrm{ACTH}$, and 3) convert radioactive precursors to biologically active corticosteroids (1-11). In contrast, in vitro human adult androgen (C-19) production has not been well studied. Lombardo and Hudson ( 7 ) and Cooper and associates (3) isolated $11 \beta$-hydroxyandrostenedione ${ }^{1}$ from the media after incubation of adrenal tissue from patients with metastatic breast carcinoma, prostatic carcinoma, and hypertension. Other C-19 steroids such as androstenedione or dehydroepiandrosterone were not identified by these workers, ${ }^{2}$ although these steroids and $11 \beta$-hydroxyandrostenedione have been demonstrated in human adrenal vein blood (14-17). The adrenal origin of the aforementioned androgens is well documented by 17 -ketosteroid secretory rate studies measured by isotope dilution $(18,19)$.

Furthermore, pathways of adrenal androgen bio-

* Supported by grants no. 254 (C-8 and C-9), C-3998, and A-4783 from the U. S. Public Health Service.

${ }^{1}$ Compounds referred to are: Pregnenolone: $3 \beta$-hydroxy-5-pregnene-20-one ; $17 \alpha$-hydroxypregnenolone: $3 \beta$,$17 \alpha$-dihydroxy-5-pregnene-20-one; progesterone : 4-pregnene-3,20-dione ; $17 \alpha$-hydroxyprogesterone: $17 \alpha$-hydroxy4-pregnene-3,20-dione; 21-deoxycortisol: $11 \beta, 17 \alpha$-dihydroxy-4-pregnene-3,20-dione ; 11-deoxycortisol, (Compound S) : 17 $\alpha, 21$-dihydroxy-4-pregnene-3,20-dione ; cortisol: $11 \beta, 17 \alpha, 21$-trihydroxy-4-pregnene-3,20-dione; dehydroepiandrosterone (DHEA) : $3 \beta$-hydroxy-5-androstene17-one; androstenedione (4-andro) : 4-androstene-3,17dione; $11 \beta$-hydroxyandrostenedione ( $11 \beta-\mathrm{OH}-4$-andro) : $11 \beta$-hydroxy-4-androstene-3,17-dione; testosterone: $17 \beta$ hydroxy-4-androstene-3-one; andrenosterone: 4-androstene-3,11,17-trione; 2,4-DNPH; 2,4-dinitrophenylhydrazone derivative; ACTH : adrenocorticotropin.

2 Plantin, Diczfalusy, and Birke identified dehydroepiandrosterone after extraction (without incubation) of a virilizing adrenal tumor removed from a 62-year-old woman (12). In addition, Anliker, Rohr, and Marti isolated testosterone from a virilizing adrenal tumor (13). synthesis in adult human tissues are also not well defined. Alternative pathways, two of which bypass progesterone have been postulated $(20,21)$ and are shown in Figure 1. Reactions 2 and 4 requiring a $3 \beta$-ol dehydrogenase and double-bond shift and reactions 1 and 3 requiring a $17 \alpha$-hydroxylase are well recognized intermediate steps for mammalian and human corticosteroid biosynthesis. In 1957, Bloch, Dorfman, and Pincus reported the conversion of acetate- $\mathrm{C}^{14}$ to $\mathrm{C}^{14}$-labeled dehydroepiandrosterone, androstenedione, and $11 \beta$-hydroxyandrostenedione by adrenal slices from a 28-year-old female with androgenital syndrome (22). Recently, Goldstein, Gut, and Dorfman (23) and Lipsett and Hökfelt (24) demonstrated dehydroepiandrosterone synthesis with adult human adrenal homogenates and slices respectively via reactions 1 and 5 (pregnenolone $\rightarrow 17 \alpha$-hydroxypregnenolone $\rightarrow$ dehydroepiandrosterone). Other alternative pathways of androgen biosynthesis were not described in these studies.

However, Solomon, Lanman, Lind, and Lieberman (25) incubated human fetal adrenal homogenates with progesterone-4-C $\mathrm{C}^{14}$ and observed 17 hydroxylation and side-chain cleavage (reactions 3 and 7, Figure 1) with the formation of androstenedione. The biosynthetic capacity of fetal adrenal slices incubated with sodium- $\mathrm{C}^{14}$ acetate was verified further by Bloch and Benirschke (26) who isolated C-21 intermediates pregnenolone and $17 \alpha$-hydroxyprogesterone and C-19 steroids-dehydroepiandrosterone, androstenedione, and $11 \beta$ hydroxyandrostenedione.

Since androgen production and biosynthetic pathways were not completely resolved in adult adrenal tissue, an investigation was undertaken to study these aspects of C-19 metabolism with "normal," atrophic, "hypertensive," hyperplastic, adenomatous adrenal gland slices. Adrenal carcinomatous tissues from two children were also 


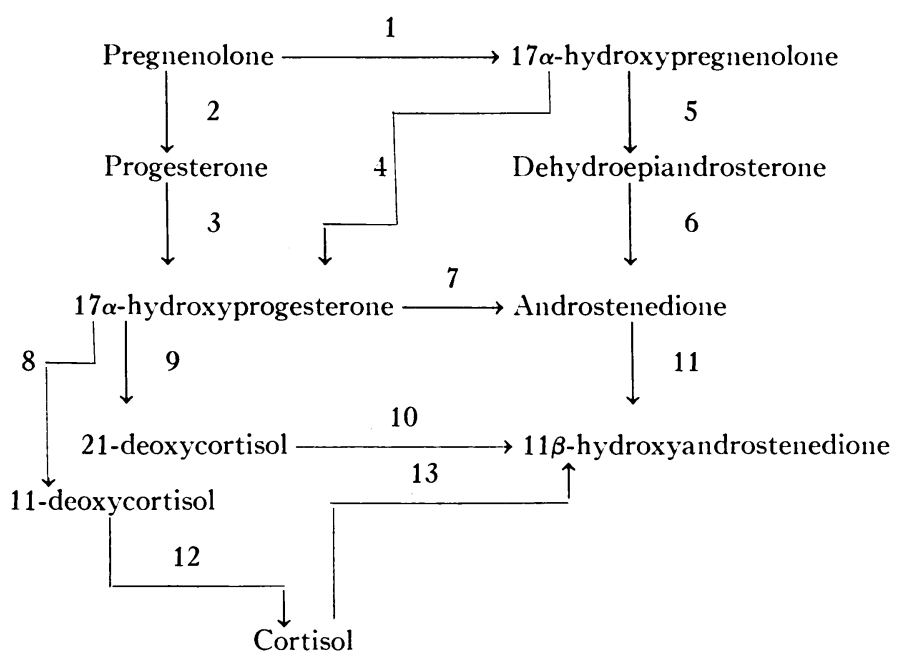

Fig. 1. POSSIble pathWAYS OF ADRENAL ANDROGEN BIOSYNTHESIS.

investigated. This paper is a report of 1) isolation, measurement, and identification of adrenal androgens released into the incubation media with slices alone and with the addition of radioactive steroid precursors and 2) the in vitro effect of ACTH on androgen release and substrate conversion. Studies of corticosteroid production and biosynthesis by some of these tissue slices were reported previously $(11,27)$.

\section{MATERIALS AND METHODS}

Subjects. The clinical subjects included eight patients with Cushing's syndrome, two with adrenal virilism, one patient with malignant hypertension (E.W.), one with a suspected pheochromocytoma (J.K.), and one with carcinoma of the prostate (J.C.) (Table I). Normal adrenocortical function was observed in Patients E.W. and J.K. but not studied in Patient J.C.

The patients with Cushing's syndrome demonstrated the typical clinical manifestations associated with the

TABLE I

Clinical and pathological findings of patients with normal and hyperadrenal function

\begin{tabular}{|c|c|c|c|c|c|c|c|c|c|}
\hline \multirow[b]{3}{*}{ Patient } & \multirow[b]{3}{*}{ Sex } & \multirow[b]{3}{*}{ Age } & \multirow[b]{3}{*}{ Clinical diagnosis } & \multirow[b]{3}{*}{ Adrenal pathology } & & & \multirow[b]{3}{*}{$\begin{array}{l}\text { Menstrual ir- } \\
\text { regularities }\end{array}$} & \multicolumn{2}{|c|}{ Laboratory } \\
\hline & & & & & \multicolumn{2}{|c|}{ Symptoms and signs } & & \multirow{2}{*}{$\begin{array}{l}17- \\
\text { Keto- } \\
\text { ster- } \\
\text { oids }\end{array}$} & \multirow{2}{*}{$\begin{array}{c}17- \\
\text { Keto- } \\
\text { genic } \\
\text { steroids }\end{array}$} \\
\hline & & & & & $\underset{\text { tion }}{\text { Masculiniza- }}$ & Hirsutism & & & \\
\hline \multicolumn{10}{|c|}{ Normal adrenal function } \\
\hline E.W.* & $\mathrm{F}$ & 47 & Malignant hypertension & Bilateral normal & Absent & Absent & Menopausal & 14.0 & 8.6 \\
\hline J.K.* & $\mathbf{M}$ & 41 & Pheochromocytoma & Right normal & Normal & Normal & & 8.4 & 7.4 \\
\hline \multirow[t]{2}{*}{ J.C. } & $\mathbf{M}$ & 63 & Carcinoma of prostate & Bilateral normal & Normal & Normal & & & \\
\hline & & & & Adrenal hyperfunction & & & & & \\
\hline L.H.* & $\mathrm{F}$ & 30 & Cushing's syndrome & $\begin{array}{l}\text { Bilateral hyperplasia } \\
\text { Right adenoma }\end{array}$ & Absent & Present & Amenorrhea & 31.5 & 48.5 \\
\hline L.J.* & $\mathrm{F}$ & 45 & Cushing's syndrome & $\begin{array}{l}\text { Left adenoma } \\
\text { Left atrophy }\end{array}$ & Absent & Present & Oligomenorrhea & 19.1 & 20.6 \\
\hline M.C. & $\mathrm{F}$ & 28 & Cushing's syndrome & $\begin{array}{l}\text { Left adenoma } \\
\text { Right atrophy }\end{array}$ & Present & Present & Amenorrhea & 22.6 & 9.2 \\
\hline G.H. & $\mathbf{F}$ & 35 & Cushing's syndrome & Bilateral hyperplasia & Absent & Present & Amenorrhea & 16.7 & 33.1 \\
\hline A.D. & $\mathbf{F}$ & 39 & Cushing's syndrome & Bilateral hyperplasia & Absent & Absent & Amenorrhea & 19.8 & 28.0 \\
\hline B.H. & $\mathbf{M}$ & 24 & Cushing's syndrome & Bilateral normal & Normal male & Normal & & 10.1 & 48.0 \\
\hline T.N.* & $\mathbf{M}$ & 12 & Cushing's syndrome & Bilateral hyperplasia & Normal male & Present & & 16.7 & 30.5 \\
\hline P.P. & $\mathbf{M}$ & 12 & Cushing's syndrome & Bilateral hyperplasia & Normal male & Absent & & 9.4 & 19.7 \\
\hline C.S.† & $\mathrm{F}$ & 3 & Adrenal virilism & $\begin{array}{l}\text { Right carcinoma } \\
\text { Left atrophy }\end{array}$ & Present & Present & & 6.8 & 2.9 \\
\hline E.S.† & $\mathbf{F}$ & $1 \frac{1}{2}$ & Adrenal virilism & Right carcinoma & Present & Present & & 2.8 & 3.0 \\
\hline
\end{tabular}

* The clinical features of these patients were summarized in a previous communication (11)

$\uparrow$ Genetic studies indicated the patients were female. No clinical stigmata of Cushing's syndrome were evident. 
disease. Laboratory studies revealed elevated 8:30 a.m. plasma cortisol levels (except L.J., whose basal level was within the normal range) and exaggerated cortisol responses to 5-hour infusions of ACTH (28). The 24hour urinary 17-ketogenic steroids (29) usually mirrored the findings in the plasma. Elevated total 17-ketosteroids were observed in six (L.H., M.C., L.J., A.D., G.H., and T.N.) of the eight patients. Gradient elution column chromatography of the urinary 17 -ketosteroids (30) of patients M.C. and L.H. revealed elevation of the 11-oxygenated 17-ketosteroids and etiocholanolone of the 11deoxy-17-ketosteroid fraction similar to the observations of Jailer, Vande Wiele, Christy, and Lieberman (31).

The clinical impression of adrenal virilism (patients E.S. and C.S.) was corroborated by normal endogenous cortisol secretion (32) and studies of corticosteroid metabolism $(27,29)$. Urinary 17 -ketosteroids were elevated, predominantly of the 11-deoxy-17-ketosteroid fractions, dehydroepiandrosterone and etiocholanolone. Adrenal cortical suppression tests were not performed. ${ }^{3}$

The patients (except L.J., whose small right adrenal gland was not removed) underwent total bilateral adrenalectomies at a one-stage operation (28); they received cortisone acetate or cortisol hemisuccinate the evening prior to and the morning of surgery. Blood and cortisol hemisuccinate were administered during the operative procedure. The pathological diagnoses of these glands are listed in Table I.

Incubation technique. The adrenal glands removed at operation were immediately iced and kept cold throughout pathological examinations and experimental procedures. The glands were weighed, sectioned, freed of fat, reweighed, and sliced with a Stadie-Riggs microtome. The medullary tissues were not separated. Slices from multiple areas of each adrenal were taken for each experimental flask. Incubation of weighed slices was performed in a Dubnoff metabolic incubator for 3 hours at $37^{\circ} \mathrm{C}$ in an atmosphere of 95 per cent oxygen, 5 per cent carbon dioxide in Krebs-Ringer bicarbonate buffer with $200 \mathrm{mg}$ per $100 \mathrm{ml}$ glucose. The incubations were started within 3 hours after excision of the adrenals. Ten units of $\mathrm{ACTH}^{4}$ per gram of tissue was added to selected flasks.

Addition of radioactive substrates. Prior to the addition of buffer and slices, certain flasks received tracer quantities of either progesterone-16- $\mathrm{H}^{3}$ (specific activity, $\mathrm{SA}, 0.506 \mathrm{mc}$ per $\mu \mathrm{mole})$, dehydroepiandrosterone $-7 \alpha-\mathrm{H}^{3}$ (SA $1.25 \mathrm{mc}$ per $\mu$ mole), or $17 \alpha$-hydroxypregnenolone- $7 \alpha$ $\mathrm{H}^{3}$ (SA $0.863 \mathrm{mc}$ per $\mu$ mole) dissolved in absolute ethanol: methanol $(1: 1)$ or benzene: methanol $(9: 1)$. In one study, approximately equimolar amounts of $17 \alpha-$ hydroxypregnenolone- $\mathrm{H}^{3}$ and progesterone-4- $\mathrm{C}^{14}$ (SA 16.2 $\mu \mathrm{c}$ per $\mu$ mole) were added. In several experiments mi-

3 The exception was C.S., a 3-year-old girl with a clinical diagnosis of "adrenogenital syndrome." Twenty $\mathrm{mg}$ of prednisone was administered per day for 30 days without effecting a change of the total urinary 17-ketosteroid excretion.

4 Armour beef adrenocorticotropin. crogram quantities of carrier steroid were also added prior to incubation. The solvents were evaporated under nitrogen or air (at $37^{\circ} \mathrm{C}$ ) and propylene glycol was added to facilitate solubilization of the substrates. The $\mathrm{C}^{14}$-labeled progesterone was purified by sequential paper chromatography in the systems of Bush C (33), petroleum ether, 75 per cent methanol, and the cyclohexane: dioxane : methanol: water $(100: 100: 50: 25)$ system of Kliman and Peterson (34). Tritium-labeled progesterone was similarly processed after the addition of unlabeled progesterone. $^{5}$ The $17 \alpha$-hydroxypregnenolone- $7 \alpha \mathrm{H}^{3}$ was subjected to three separate solvent partitionings in $n$-hexane : ethanol: water $(100: 2: 98 \mathrm{vol} / \mathrm{vol})$ at $2^{\circ} \mathrm{C}, n$-hexane: ethanol: water $(100: 20: 80: \mathrm{vol} / \mathrm{vol})$ at $25^{\circ} \mathrm{C}$, and $n$-hexane: carbon tetrachloride: ethanol: water $(30: 70$ : $47.5: 52.5 \mathrm{vol} / \mathrm{vol})$ at $25^{\circ} \mathrm{C}$ as described by Carstensen, Oertel, and Eik-Nes (35). The compound was stored in a frozen state in benzene: methanol (9:1) until useci. Radiochemical homogeneity was observed after the addition of stable $17 \alpha$-hydroxypregnenolone and paper chromatography in cyclohexane: benzene: methanol: water $(100: 50: 100: 25)$ and toluene: propylene glycol systems followed by reverse phase paper chromatography in the benzene: petroleum ether:methanol: water (20:10:40: 10) system. A second minor peak of radioactivity estimated to contain less than 5 per cent of the radioactivity of the $17 \alpha$-hydroxypregnenolone peak was noted in one system. The preparation and purification of dehydroepiandrosterone- $7 \alpha-\mathrm{H}^{3}$ from the acetate derivative were described previously (36). Dehydroepiandrosterone- $7 \alpha-\mathrm{H}^{3}$ was chromatographed in the heptane: 96 per cent methanol system (37) within 72 hours of use.

Steroid separation and measurement. After incubation. the media were carefully decanted, and the tissues and flasks were washed three times with cold isotonic saline. The appropriate media and washings were pooled. In order to correct for chemical losses incurred during manipulations, tracers of tritium-labeled dehydroepiandrosterone, SA $1.25 \mathrm{mc}$ per $\mu$ mole; androstenedione-4- $\mathrm{C}^{14}$, SA $2.13 \mu \mathrm{c}$ per $\mu$ mole; and $11 \beta$-hydroxyandrostenedione- $4-C^{14}, 6$ SA $1.4 \mu \mathrm{c}$ per $\mu$ mole, were added to some media prior to extraction (with the exception of the radioactive conversion studies). Constant specific activities of the free C-19 tracers were observed after reverse isotope dilution with paper chromatography.

The pooled washings and media were extracted twice with 3 volumes of dichloromethane which had been purified by passage through a silica-gel column. The dichloromethane extract was washed once with $1 / 10$ volume of $0.05 \mathrm{~N}$ sodium hydroxide and twice with $1 / 10$ volume of distilled water. The water was removed with anhydrous sodium sulfate and the extract evaporated in

${ }^{5}$ The tritium-labeled steroids were purchased from the New England Nuclear Corp., Boston, Mass. Progesterone-4-C $\mathrm{C}^{14}$ was generously donated by the Endocrine Study Section, National Institute of Health, Bethesda, Md.

${ }^{6}$ Dr. H. Leon Bradlow, Sloan-Kettering Institute, New York, N. Y. graciously made this isotope available. 
vacuo at $37^{\circ} \mathrm{C}$. The residues were applied to washed Whatman no. 1 filter paper and developed for 72 hours in a modification of the toluene: propylene glycol system (38).$^{7}$ The effluents were collected and chromatographed for 20 hours in the cyclohexane: dioxane: methanol: water system $(100: 100: 50: 25)$ which separated corticosteroids (corticosterone and 11-deoxycortisol) (34) from androgens. Dehydroepiandrosterone and androstenedione ran off the paper and were collected. On occasion the more polar C-19 steroids were located at the bottom of the paper. The effluents and paper eluates 8 were dried in vacuo and transferred quantitatively with chloroform to washed Whatman no. 1 filter paper $(28 \times 1$ inch strips with a common origin) in the heptane: 96 per cent methanol (1:1) system of Bush and Willoughby. Fifteen to twenty $\mu \mathrm{g}$ each of reference compounds, dehydroepiandrosterone, androstenedione, $11 \beta$-hydroxyandrostenedione, and adrenosterone were applied together in a single spot on each side of the "extract area." The paper was equilibrated for 4 hours and the mobile phase allowed to develop for 14 to 16 hours, ${ }^{9}$ after which the paper was air dried. The C-19 steroids with a $\lrcorner^{+}-3$-ketone configuration were located on the chromatograms by the ultraviolet scanning technique and the $\Delta^{5}-3 \beta$-ol steroid (dehydroepiandrosterone standard) by Zimmermann reagent stain (alkaline $m$-dinitrobenzene). Appropriate areas corresponding to the standards and paper blanks were cut out and eluted with $4.0 \mathrm{ml}$ of absolute ethanol as previously described (36).

Measurements of the isolated androgens with a $د^{4}-3$-ketone configuration were performed on portions of the eluates by the alkaline fluorescent method of Abelson and Bondy (39). Authentic androstenedione was used in construction of the standard curve. The $\mathrm{C}-19$ steroids were determined also by absorbance $(0.8 \mathrm{ml}$ microcuvets with a $1.0 \mathrm{~cm}$ light path) at $240 \mathrm{~m} \mu$ (ethanol) in a Beckman model DU spectrophotometer. The extinction coefficients at $240 \mathrm{~m} \mu$ were used for the chemical determination. Dehydroepiandrosterone was converted to the 2,4-dinitrophenylhydrazone derivative and measured spectrophotometrically at $368 \mathrm{~m} \mu(36)$.

A $0.5 \mathrm{ml}$ portion of the ethanol eluate was counted to a standard error of \pm 2 per cent in a liquid phosphor scintillation counter (Model LP-2, Technical Measurements Corp., New Haven, Conn.), which had a counting efficiency of 45 to 48 per cent for carbon-14. The tritiumlabeled dehydroepiandrosterone 2,4-dinitrophenylhydrazone was plated at infinite thinness on aluminum planchets and counted to a \pm 2 per cent standard error in a windowless gas-flow counter (Automatic Sample Changer,

${ }^{7}$ The stationary phase was propylene glycol diluted with methanol $(1: 1)$ before application to the paper. The methanol was then allowed to evaporate.

${ }^{8}$ Radioactive C-19 tracers were added at this stage of the steroid isolation if omitted previously, in order to correct for losses in purification.

9 Paper chromatography of the 17 -ketosteroids was carried out in a room maintained at a constant temperature of $20^{\circ} \mathrm{C}$ and relative humidity of less than 50 per cent.
Model C110 B, Nuclear-Chicago Corp., Des Plaines, I11.). The efficiency for tritium was 18 to 20 per cent. The final value was determined, taking into account the absorbance of the blank, chemical amount of the added carbon-14 tracer $(0.20 \mu \mathrm{g}$ or less $)$, dilution factor, and the isotope recovery (40). Since the chemical amount of the added dehydroepiandrosterone tracer was less than $0.01 \mu \mathrm{g}$, the steroid was calculated as the free compound without chemical correction. The calculation of the androgens isolated from media of the radioactive conversion experiments was uncorrected for isotope recovery, although other results were so corrected.

Identification. The isolated androgens from the incubations zeithout added radioactive substrates were pooled separately. The identification of $\Delta^{4}$-3-keto C-19 steroids was substantiated by characteristic mobilities and constant specific activities in two additional paper chromatographic systems, heptane:propylene glycol (41) and ligroin : benzene : methanol: water $(667: 333: 800: 200)$ (42). Areas of ultraviolet absorption and Zimmermann positive staining coincided with the radioactive peaks located by a gas-flow paper chromatogram scanner (Model C-100 B, Actigraph II, Nuclear-Chicago Corp., Des Plaines, Ill.). Androstenedione- $\mathrm{C}^{14}$ and $11 \beta$-hydroxyandrostenedione- $\mathrm{C}^{14}$ bis-2,4-dinitrophenylhydrazones were formed (prior acetylation was unsuccessful) and confirmed by characteristic absorption maxima of 378 to 380 $\mathrm{m} \mu$ (22) in the Beckman DU spectrophotometer. The specific activities of the hydrazones were determined by absorbance at $378 \mathrm{~m} \mu$ and calculated for the free compound. Radioactivity was measured by counting at infinite thinness on aluminum planchets to a standard error of \pm 2 per cent in the Nuclear-Chicago, Model C-110 $\mathrm{B}$ micro-window gas-flow counter. The efficiency for $\mathrm{C}^{14}$ was 24 to 28 per cent by this technique.

Dehydroepiandrosterone was verified as the mono-2, 4-dinitrophenylhydrazone derivative by the following criteria : 1) absorption maximum of $368 \mathrm{~m} \mu$ (chloroform); 2) characteristic position of only one radioactive peak on elution from micro-alumina columns (36); and 3 ) mobility of the mono-2,4-dinitrophenylhydrazone $(1 \mathrm{~cm}$ per hour) developed for 12 hours in the heptane: propylene glycol system (22). The appropriate yellow radioactive area and paper blanks were cut into thirds, eluted with chloroform, and specific activities determined by spectrophotometry and windowless planchet counting with the Nuclear-Chicago Model C-110 B gas-flow counter. The specific activities were calculated on the basis of free dehydroepiandrosterone.

Radioactive androgens from the precursor experiments were identified after paper chromatographic separation and spectrophotometric and isotope measurements. One hundred micrograms of carrier androstenedione, $11 \beta$-hydroxyandrostenedione, and dehydroepiandrosterone were added to pooled paper eluates from experiments with a common radioactive substrate. The separate eluates were dried in vacuo at $37^{\circ} \mathrm{C}$ and the dried residues of each $\Delta^{4}$-3-ketone androgen product subjected to a 40-tube countercurrent distribution (E-C Apparatus Company, 
TABLE II

Androgen production by "normal," atrophic, and "hypertensive" adrenal glands

\begin{tabular}{|c|c|c|c|c|c|}
\hline \multirow[b]{2}{*}{ Patient } & \multirow[b]{2}{*}{ Pathology } & \multirow{2}{*}{$\begin{array}{c}\text { Wt of } \\
\text { incubated } \\
\text { tissue }\end{array}$} & \multicolumn{3}{|c|}{ Steroids* } \\
\hline & & & DHEA & $\begin{array}{c}\text { Andro- } \\
\text { stenedione }\end{array}$ & $\begin{array}{c}11 \beta-\mathrm{OH}-4 \\
\text { Andro }\end{array}$ \\
\hline & & $g$ & \multicolumn{3}{|c|}{$\mu g / g / 3$ hrs $\dagger$} \\
\hline J.K. & "Normal" & 1.661 & 2.6 & 2.9 & 1.5 \\
\hline J.C: & "Normal" & 2.524 & 0.4 & 1.8 & 1.5 \\
\hline L.J.J. & Atrophic & 0.984 & 0 & 1.1 & 2.0 \\
\hline \multirow{3}{*}{ M.C. } & Atrophic + ACTH $\ddagger$ & 0.474 & 4.4 & 3.8 & 17.7 \\
\hline & Atrophic & 0.700 & 14.3 & 0 & 0 \\
\hline & Atrophic + ACTH $\ddagger$ & 0.158 & 5.3 & 2.7 & 34.2 \\
\hline \multirow[t]{2}{*}{ E.W. } & Left hypertension & 0.573 & 0 & 3.5 & 5.4 \\
\hline & Right hypertension & 0.570 & 0 & 3.7 & 4.9 \\
\hline
\end{tabular}

* DHEA, dehydroepiandrosterone; $11 \beta$-OH-4 andro, $11 \beta$-hydroxyandrostenedione.

$\dagger$ The total mean $\pm S D$ per cent recoveries of $\mathrm{C}^{14}$ - and tritium-labeled tracers added to media before extraction were $49 \pm 8.2$. The total per cent isotopic recoveries for tracers added to effluents and eluates from cyclohexane:dioxane: methanol: water system were $82 \pm 10.1$.

$\ddagger$ The amount of ACTH added was 10 units per gram of tissue.

Swarthmore, Pa.) at room temperature. Theoretical countercurrent distribution curves were calculated according to the procedure of Way and Bennett (43). The solvent system employed for androstenedione $(K=0.397)$ and $11 \beta$-hydroxyandrostenedione $(\mathrm{K}=0.178)$ was ethyl acetate : hexane : methanol: water $(120: 180: 180: 120)$. A 20-tube transfer was carried out for dehydroepiandrosterone in the ethyl acetate: cyclohexane: ethanol: water $(30: 70: 55: 45)$ system, $K=1.02$, of Savard and collaborators (44). At the end of the distribution, the total contents of each tube $(20 \mathrm{ml})$ were transferred to test tubes and dried in air at $37^{\circ} \mathrm{C}$. After specific activities were determined as described, the residues were dissolved in ethanol, and the peak tube and the two adjoining tubes on both sides of the peak pooled for further identification. Mobilities and specific activities of the free steroids and 2,4-dinitrophenylhydrazone derivatives were calculated after paper (Bush and Zaffaroni systems) and microalumina column chromatographic separation, respectively. ${ }^{10}$ In addition, a portion of the pooled transfers from the countercurrent distribution of $11 \beta$-hydroxyandrostenedione from one series of incubations with $17 \alpha-$ hydroxypregnenolone- $\mathrm{H}^{3}$ was oxidized with chromic acid

10 Only dehydroepiandrosterone 2,4-dinitrophenylhydrazone was chromatographed on alumina columns.

TABLE III

Androgen production by hyperplastic, "normal," adenomatous, and carcinomatous tissue from patients with adrenal hyperfunction

\begin{tabular}{|c|c|c|c|c|c|c|c|c|c|}
\hline \multirow[b]{2}{*}{ Patient } & \multirow[b]{2}{*}{ Pathology } & \multirow{2}{*}{$\begin{array}{c}\text { Wt of } \\
\text { incubated } \\
\text { tissue }\end{array}$} & \multicolumn{3}{|c|}{ Steroids* } & \multirow{2}{*}{$\begin{array}{c}\text { Wt of incubated } \\
\text { tissue }\end{array}$} & \multicolumn{3}{|c|}{ Steroids (with ACTH†) } \\
\hline & & & DHEA & 4-Andro & $\begin{array}{c}11 \beta-O H-4 \\
\text { Andro }\end{array}$ & & DHEA & 4-Andro & $\begin{array}{c}11 \beta-\mathrm{OH}-4 \\
\text { Andro }\end{array}$ \\
\hline & & $g$ & \multicolumn{3}{|c|}{$\mu g / g / 3$ hrs } & $\begin{array}{c}g \\
\text { Cushing's syndrome }\end{array}$ & \multicolumn{3}{|c|}{$\mu g / g / 3$ hrs } \\
\hline L.H. & $\begin{array}{l}\text { R. hyperplasia } \\
\text { L. hyperplasia } \\
\text { R. adenoma }\end{array}$ & $\begin{array}{l}1.005 \\
1.025 \\
1.845\end{array}$ & $\begin{array}{l}0 \\
0 \\
2.3\end{array}$ & $\begin{array}{l}3.1 \\
3.6 \\
0.9\end{array}$ & $\begin{array}{r}11.3 \\
8.7 \\
3.4\end{array}$ & $\begin{array}{r}1.010 \\
.500 \\
1.200\end{array}$ & $\begin{array}{l}0 \\
0 \\
2.5\end{array}$ & $\begin{array}{r}4.1 \\
12.6 \\
11.7\end{array}$ & $\begin{array}{l}25.0 \\
47.4 \\
15.0\end{array}$ \\
\hline T.N. & $\begin{array}{l}\text { R. hyperplasia } \\
\text { L. hyperplasia }\end{array}$ & $\begin{array}{l}2.056 \\
2.482\end{array}$ & $\begin{array}{l}\mathbf{0} \\
\mathbf{0}\end{array}$ & $\begin{array}{l}\mathbf{0} \\
\mathbf{0}\end{array}$ & $\begin{array}{l}4.3 \\
3.8\end{array}$ & $\begin{array}{l}2.008 \\
2.532\end{array}$ & $\begin{array}{l}\mathbf{0} \\
\mathbf{0}\end{array}$ & $\begin{array}{l}1.0 \\
0\end{array}$ & $\begin{array}{l}6.3 \\
5.2\end{array}$ \\
\hline P.P. & $\begin{array}{l}\text { R. hyperplasia } \\
\text { L. hyperplasia }\end{array}$ & $\begin{array}{l}0.984 \\
1.027\end{array}$ & $\begin{array}{l}1.3 \\
0\end{array}$ & $\begin{array}{l}0 \\
1.2\end{array}$ & $\begin{array}{l}4.3 \\
1.2\end{array}$ & $\begin{array}{r}1.326 \\
.986\end{array}$ & $\begin{array}{l}0.7 \\
0.8\end{array}$ & $\begin{array}{l}0 \\
1.6\end{array}$ & $\begin{array}{l}2.6 \\
2.1\end{array}$ \\
\hline A.D. & L. hyperplasia & 1.019 & 0 & 1.3 & 0.9 & 1.008 & $\mathbf{0}$ & 0.7 & 1.3 \\
\hline B.H. & $\begin{array}{l}\text { R. "normal" } \\
\text { L. "normal" }\end{array}$ & $\begin{array}{l}1.033 \\
0.977\end{array}$ & $\mathbf{0}$ & 4.5 & $\mathbf{0}$ & $\begin{array}{r}1.010 \\
.992\end{array}$ & $\begin{array}{l}0 \\
1.6\end{array}$ & $\begin{array}{l}1.2 \\
0.6\end{array}$ & $\begin{array}{l}4.6 \\
4.2\end{array}$ \\
\hline L.J. & Adenoma & 1.554 & $\mathbf{0}$ & 1.3 & 3.0 & 1.544 & 1.5 & 0 & 6.6 \\
\hline M.C. & Adenoma & 2.380 & $\mathbf{0}$ & 3.3 & 7.4 & 2.406 & 0 & 1.8 & 6.3 \\
\hline & & & & & & Adrenal virilism & & & \\
\hline c.s. & Carcinoma & 1.504 & 2.7 & 0 & $\mathbf{0}$ & 1.508 & 4.5 & 2.7 & $\mathbf{0}$ \\
\hline E.S. & Carcinoma & 1.007 & 0 & 0 & 8.0 & .940 & 3.5 & 8.9 & 12.9 \\
\hline
\end{tabular}

* DHEA, dehydroepiandrosterone; 4-andro, androstenedione; $11 \beta-O H-4$ andro, $11 \beta$-hydroxyandrostenedione.

$\dagger 10$ units of ACTH per gram of tissue. 
according to the method of Lieberman and collaborators (45). The identity of the radioactive product, adrenosterone, was verified by its characteristic mobility on paper in the heptane: propylene glycol and 96 per cent methanol: heptane systems. The identical ultraviolet light absorbing and radioactive zone from each chromatogram was eluted and specific activities determined by planchet counting and absorbance at $240 \mathrm{~m} \mu$ as described.

\section{RESULTS}

\section{A. Adrenal androgen production}

Three adrenal androgens, dehydroepiandrosterone. $11 \beta$-hydroxyandrostenedione, and androstenedione were isolated from the media after 3-hour incubation. Adrenosterone was not detected. In Table II is listed the steroid production ( $\mu \mathrm{g}$ per gram of slice) by tissue slices from patients with normal and with atrophic adrenals. The results of Patients J.K. and J.C. represent the pattern of production by "normal" tissues. The functional capacity of the atrophic glands (L.J., ipsilateral, and M.C., contralateral) is indicated by the endogenous and ACTH-stimulated androgen release, especially the striking increase in $11 \beta$-hydroxyandrostenedione. The "hypertensive" glands of $\mathrm{Pa}$ tient E.W. produced $11 \beta$-hydroxyandrostenedione and androstenedione at a rate comparable with that of adrenal tissue from some patients with Cushing's syndrome.

The androgen production by adrenal slices from patients with Cushing's syndrome and adrenal virilism is listed in Table III. Small amounts of endogenous dehydroepiandrosterone were detected in incubations of adenomatous (L.H.), hyperplastic (P.P.), and carcinomatous tissues (C.S.). The addition of ACTH to the system did not stimulate dehydroepiandrosterone production consistently. However, ACTH stimulated the carcinomatous tissues (C.S. and E.S.) to produce amounts of dehydroepiandrosterone in the range of the atrophic tissues of L.J. and M.C. (Table II).

On the other hand, incubation of "Cushing adrenal tissue" (Table III) in the presence of ACTH resulted in a one and a half to sixfold increment of $11 \beta$-hydroxyandrostenedione production. Nevertheless, the most exaggerated $11 \beta$ hydroxyandrostenedione response to $\mathrm{ACTH}$ is found in the atrophic tissues (Table II), associated clinically with adenomata.

The effect of ACTH on androstenedione release

TABLE IV

Total androgen production per gland

\begin{tabular}{|c|c|c|c|c|c|c|c|c|c|c|}
\hline \multirow[b]{2}{*}{ Patient } & \multirow[b]{2}{*}{ Pathology } & \multirow{2}{*}{$\begin{array}{c}\text { Total } \\
\text { weight of } \\
\text { tissue* }\end{array}$} & \multicolumn{3}{|c|}{ Steroids $\dagger$} & \multirow[b]{2}{*}{ Total } & \multicolumn{3}{|c|}{ Steroids (with ACTH) } & \multirow[b]{2}{*}{ Total } \\
\hline & & & DHEA & 4-Andro & 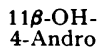 & & DHEA & 4-Andro & $\begin{array}{l}\text { 11B-OH- } \\
\text { 4-Andro }\end{array}$ & \\
\hline & & $g$ & \multicolumn{3}{|c|}{$\mu g /$ gland $/ 3$ hrs } & & \multicolumn{4}{|c|}{$\mu g / g l a n d / 3$ hrs } \\
\hline J.K. & Normal & 8.3 & 21.6 & 24.1 & 12.5 & 58.2 & & & & \\
\hline J.C. & Normal & 4.7 & 1.9 & 8.5 & 7.1 & 17.5 & & & & \\
\hline E.W. & $\begin{array}{l}\text { L. hypertension } \\
\text { R. hypertension }\end{array}$ & $\begin{array}{l}16.0 \\
12.5\end{array}$ & $\begin{array}{l}\mathbf{0} \\
\mathbf{0}\end{array}$ & $\begin{array}{l}56.0 \\
46.3\end{array}$ & $\begin{array}{l}86.4 \\
61.3\end{array}$ & $\begin{array}{l}142.4 \\
107.4\end{array}$ & & & & \\
\hline L.H. & $\begin{array}{l}\text { L. hyperplasia } \\
\text { R. hyperplasia } \\
\text { R. adenoma }\end{array}$ & $\begin{array}{l}13.5 \\
12.5 \\
32.0\end{array}$ & $\begin{array}{c}0 \\
0 \\
73.6\end{array}$ & $\begin{array}{l}48.6 \\
38.8 \\
28.8\end{array}$ & $\begin{array}{l}117.5 \\
141.3 \\
108.8\end{array}$ & $\begin{array}{l}166.1 \\
180.1 \\
211.2\end{array}$ & $\begin{array}{r}0 \\
0 \\
80\end{array}$ & $\begin{array}{r}170.1 \\
51.3 \\
374.4\end{array}$ & $\begin{array}{l}639.9 \\
312.5 \\
480.0\end{array}$ & $\begin{array}{l}810 \\
363.8 \\
934.4\end{array}$ \\
\hline L.J. & $\begin{array}{l}\text { L. adenoma } \\
\text { R. atrophic }\end{array}$ & $\begin{array}{c}22.02 \\
3.0\end{array}$ & $\begin{array}{l}\mathbf{0} \\
\mathbf{0}\end{array}$ & $\begin{array}{r}28.6 \\
3.3\end{array}$ & $\begin{array}{r}66 \\
6\end{array}$ & $\begin{array}{r}94.6 \\
9.3\end{array}$ & $\begin{array}{l}33 \\
13.2\end{array}$ & $\begin{array}{c}0 \\
11.8\end{array}$ & $\begin{array}{r}145.2 \\
53.1\end{array}$ & $\begin{array}{r}178.2 \\
77.7\end{array}$ \\
\hline M.C. & $\begin{array}{l}\text { L. adenoma } \\
\text { R. atrophic }\end{array}$ & $\begin{array}{r}51.9 \\
0.7\end{array}$ & $\begin{array}{c}0 \\
10.0\end{array}$ & $\begin{array}{c}171.3 \\
0\end{array}$ & $\begin{array}{c}384.1 \\
0\end{array}$ & $\begin{array}{c}555.4 \\
10.0\end{array}$ & $\begin{array}{l}0 \\
3.7\end{array}$ & $\begin{array}{r}93.4 \\
1.9\end{array}$ & $\begin{array}{c}327 \\
23.9\end{array}$ & $\begin{array}{r}420.4 \\
29.5\end{array}$ \\
\hline A.D. & L. hyperplasia & 18.0 & $\mathbf{0}$ & 23.4 & 16.2 & 39.6 & $\mathbf{0}$ & 12.6 & 23.4 & 36 \\
\hline B.H. & $\begin{array}{l}\text { L. normal } \\
\text { R. normal }\end{array}$ & $\begin{array}{l}4.0 \\
5.2\end{array}$ & $\mathbf{0}$ & 18.0 & $\mathbf{0}$ & 18.0 & $\begin{array}{l}6.4 \\
0\end{array}$ & $\begin{array}{l}2.4 \\
6.2\end{array}$ & $\begin{array}{l}16.8 \\
23.9\end{array}$ & $\begin{array}{l}25.6 \\
30.1\end{array}$ \\
\hline T.N. & $\begin{array}{l}\text { L. hyperplasia } \\
\text { R. hyperplasia }\end{array}$ & $\begin{array}{l}11.5 \\
14.5\end{array}$ & $\begin{array}{l}0 \\
0\end{array}$ & $\begin{array}{l}\mathbf{0} \\
\mathbf{0}\end{array}$ & $\begin{array}{l}43.7 \\
62.4\end{array}$ & $\begin{array}{l}43.7 \\
62.4\end{array}$ & $\begin{array}{l}0 \\
0\end{array}$ & $\begin{array}{c}0 \\
14.5\end{array}$ & $\begin{array}{l}59.8 \\
91.4\end{array}$ & $\begin{array}{r}59.8 \\
105.9\end{array}$ \\
\hline P.P. & $\begin{array}{l}\text { L. hyperplasia } \\
\text { R. hyperplasia }\end{array}$ & $\begin{array}{l}7.7 \\
6.7\end{array}$ & $\begin{array}{l}0 \\
8.7\end{array}$ & $\begin{array}{l}9.2 \\
0\end{array}$ & $\begin{array}{r}9.2 \\
28.8\end{array}$ & $\begin{array}{l}18.4 \\
37.5\end{array}$ & $\begin{array}{l}6.2 \\
4.7\end{array}$ & $\begin{array}{c}12.3 \\
0\end{array}$ & $\begin{array}{l}16.2 \\
17.4\end{array}$ & $\begin{array}{l}34.7 \\
22.1\end{array}$ \\
\hline c.s. & R. carcinoma & 9.0 & 24.3 & $\mathbf{0}$ & 0 & 24.3 & 40.5 & 24.3 & 0 & 64.8 \\
\hline E.S. & R. carcinoma & 7.2 & $\mathbf{0}$ & $\mathbf{0}$ & 57.6 & 57.6 & 25.2 & 64.1 & 92.9 & 182.2 \\
\hline
\end{tabular}

* These values represent weights of the trimmed pathological specimen.

$t$ Abbreviations as described in Tables II and III. 
TABLE V

Specific activities of pooled androgens obtained from human adrenal slice incubations

\begin{tabular}{|c|c|c|c|c|}
\hline Steroid * & Method & Solvent system & & $\begin{array}{c}\text { Specific activity } \\
\text { Dehydroepiandros- } \\
\text { teronet }\end{array}$ \\
\hline \multirow[t]{7}{*}{ Mono-2,4-DNPH derivative $\ddagger$} & & & & $\underset{20,818 \|}{c p m / \mu m o l e}$ \\
\hline & Column chromatography $\S$ & & & \\
\hline & $3.9 \%$ Hydration & Benzene :chloroform $(4: 1)$ & & 20,523 \\
\hline & $5.0 \%$ Hydration & Benzene: chloroform $(4: 1)$ & & 20,469 \\
\hline & Paper chromatography & Upper third & & 20,364 \\
\hline & Heptane: propylene glycol & Middle third & & 20,148 \\
\hline & & Lower third & & 20,287 \\
\hline \multirow[t]{3}{*}{ Free compounds } & & & $\begin{array}{c}11 \beta-\mathrm{OH}-4- \\
\text { androstenedione } \\
8,048 \|\end{array}$ & $\begin{array}{c}\text { Androstenedione } \\
10,708 \|\end{array}$ \\
\hline & Paper chromatography & $96 \%$ Methanol: benzene $(1: 1)$ & 7,748 & 10,255 \\
\hline & & Heptane:propylene glycol & 7,508 & 10,340 \\
\hline Bis-2,4-DNPH derivative & & $\begin{array}{l}\text { Ligroin: benzene : methanol: } \\
\text { water }(667: 333: 800: 200)\end{array}$ & $\begin{array}{l}7,547 \\
7,540\end{array}$ & $\begin{array}{l}10,028 \\
10,001\end{array}$ \\
\hline
\end{tabular}

* The chemical amount of the steroid 2,4-DNPH was measured at $368 \mathrm{~m} \mu$ (mono) and $378 \mathrm{~m} \mu$ (bis) in a spectrophotometer. Radioactive measurements were performed with a windowed $\left(\mathrm{C}^{14}\right)$ and windowless $\left(\mathrm{H}^{3}\right)$ gas-flow counter. The efficiency for $\mathrm{C}^{14}$ was 24 to 28 per cent.

$t$ The specific activity is calculated on the basis of the free compound.

2,4-DNPH, 2,4-dinitrophenylhydrazone.

The steroid 2,4-DNPH was chromatographed on $1,000 \mathrm{mg}$ of neutral aluminum oxide (Woelm) $12.5 \times 0.3 \mathrm{~cm}$ column.

II Specific activity of free androgen.
Specific activity of pooled androgens prior to identification procedures.

is marked in the left hyperplastic and adenomatous tissues of L.H. and carcinomatous slices from $\mathrm{Pa}$ tient E.S. (Table III).

The amounts of androstenedione are decreased rather than increased in most other incubations with ACTH. The total androgen production per gland by all tissues is shown in Table IV. These results are based on the assumption that the incubated tissue is representative of the entire gland. The total production of $11 \beta$-hydroxyandrostenedione in the absence of ACTH by the hyperplastic, adenomatous, and carcinomatous tissues (except Patients C.S., B.H., and P.P.) is consistently greater than that of the "normal" and atrophic glands. The total androgen production of the "hypertensive" glands (E.W.) is comparable to "Cushing tissue."

The elevated total urinary 17-ketosteroid levels of Patients L.H., M.C., L.J., and T.N. (Cushing's syndrome) correlated well with the increased total adrenal androgen production in vitro. A similar correlation is present in Patients C.S. and E.S. with adrenal carcinoma and virilism. The functional in vitro capacity of the contralateral atrophic glands of C.S. and E.S. is not known.

Identification of adrenal androgens without addition of radioactive precursors. After chemical and radioactive measurements were performed,

TABLE VI

Incubation of adrenal slices with progesterone-16- $H^{3}$

\begin{tabular}{|c|c|c|c|c|c|c|c|c|c|c|c|c|}
\hline \multirow{3}{*}{ Patient } & \multirow{3}{*}{ Pathology } & \multicolumn{2}{|c|}{$\begin{array}{c}\text { Substrate } \\
\text { Progesterone-16- } \mathrm{H}^{3} \\
\end{array}$} & \multirow{3}{*}{$\frac{\begin{array}{c}\text { Weight of } \\
\text { tissue }\end{array}}{g}$} & \multicolumn{8}{|c|}{ Products } \\
\hline & & \multirow{2}{*}{$\frac{\mathrm{SA}}{\mu c / \mu m o l e}$} & \multirow{2}{*}{$\frac{\begin{array}{c}\text { Amount } \\
\text { added }\end{array}}{\mu c}$} & & \multicolumn{4}{|c|}{ Androstenedione } & \multicolumn{4}{|c|}{$11 \beta-$ Hydroxyandrostenedione } \\
\hline & & & & & $\begin{array}{c}\mu g / g / \\
3 \mathrm{hrs}\end{array}$ & $\begin{array}{c}\mu c / \\
\text { umole }\end{array}$ & $\%$ conv.* & $\begin{array}{c}\text { Ratio } \\
S A \dagger\end{array}$ & $\begin{array}{c}\mu g / g / \\
3 \mathrm{hrs}\end{array}$ & $\begin{array}{c}\mu c / \\
\mu m o l e\end{array}$ & $\% \operatorname{conv}$. & $\begin{array}{l}\text { Ratio } \\
S A\end{array}$ \\
\hline J.K. & "Normal" & 50.3 & 27 & 2,734 & 2.5 & 1.34 & 0.12 & 0.027 & 1.8 & 3.29 & 0.20 & 0.065 \\
\hline L.H. & $\begin{array}{l}\text { Right hyperplasia } \\
\text { Adenoma }\end{array}$ & $\begin{array}{l}72.6 \\
72.6\end{array}$ & $\begin{array}{l}4.6 \\
9.12\end{array}$ & $\begin{array}{r}510 \\
1,200\end{array}$ & $\begin{array}{l}2.4 \\
2.8\end{array}$ & $\begin{array}{l}0.32 \\
2.46\end{array}$ & $\begin{array}{l}0.03 \\
0.32\end{array}$ & $\begin{array}{l}0.0044 \\
0.034\end{array}$ & $\begin{array}{l}8.5 \\
2.1\end{array}$ & $\begin{array}{l}1.96 \\
4.34\end{array}$ & $\begin{array}{r}0.061 \\
0.40\end{array}$ & $\begin{array}{l}0.027 \\
0.059\end{array}$ \\
\hline L.J. & Adenoma & 40.8 & 5.3 & 1,010 & 1.2 & 0.21 & 0.016 & 0.0051 & 2.5 & 5.05 & 0.80 & 0.124 \\
\hline
\end{tabular}

* Per cent conversion of radioactive substrate to androstenedione and $11 \beta$-hydroxyandrostenedione measured after paper chromatography in the heptane: 96 per cent methanol system.

+ Ratio SA is the ratio of the specific activity of the product to the specific activity of the substrate. 

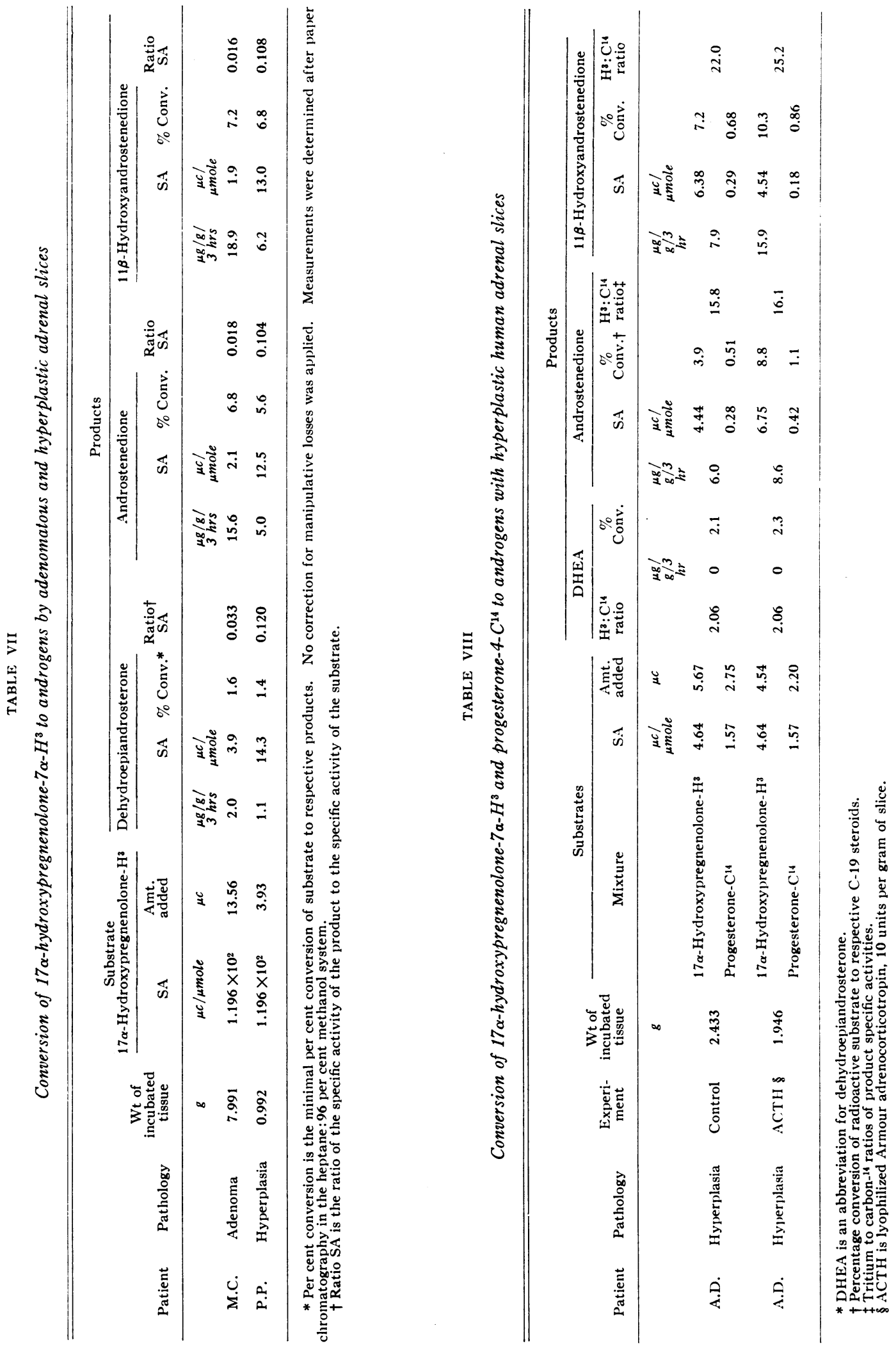
TABLE IX

The conversion of dehydroepiandrosterone- $H^{3}$ to androstenedione- $H^{3}$ and $11 \beta$-hydroxyandrostenedione- $H^{3}$ by hyperplastic adrenal slices

\begin{tabular}{|c|c|c|c|c|c|c|c|c|c|c|}
\hline \multirow[b]{3}{*}{ Patient } & \multirow[b]{3}{*}{ Pathology } & \multirow[b]{3}{*}{$\begin{array}{l}\text { Wt. of } \\
\text { tissue }\end{array}$} & \multicolumn{8}{|c|}{ Products } \\
\hline & & & \multicolumn{2}{|c|}{$\begin{array}{c}\text { Dehydroepiandros- } \\
\text { terone-H3 }\end{array}$} & \multicolumn{3}{|c|}{ Androstenedione } & \multicolumn{3}{|c|}{$\begin{array}{c}11 \beta \text {-Hydroxyandro- } \\
\text { stenedione }\end{array}$} \\
\hline & & & SA & $\begin{array}{l}\text { Amt. } \\
\text { added }\end{array}$ & & SA & $\begin{array}{c}\% \\
\text { Conv. }\end{array}$ & & SA & $\begin{array}{c}\% \\
\text { Conv. }\end{array}$ \\
\hline & & $g$ & $\mu c / \mu m o l e$ & $\mu c$ & $\begin{array}{c}\mu g / g / \\
3 \mathrm{hr}\end{array}$ & $\begin{array}{c}\mu c / \\
\mu m o l e\end{array}$ & & $\begin{array}{c}\mu g / g / \\
3 \mathrm{hr}\end{array}$ & $\underset{\mu m o l e}{\mu c /}$ & \\
\hline G.H. & Right hyperplasia & 2.997 & 31.53 & 6.43 & 23.2 & 2.55 & 9.7 & 38.5 & 2.76 & 16.5 \\
\hline
\end{tabular}

the remainder of the eluates (from the 96 per cent methanol: heptane system) were pooled and specific activities determined. Radiochemical homogeneity of the isolated androgens is demonstrated by the data in Table V.

\section{B. Radioactive precursor conversion studies}

In Table VI are listed the data from the incubation of "normal" and pathological adrenal slices with progesterone-16- $\mathrm{H}^{3}$. Radioactive androstenedione and $11 \beta$-hydroxyandrostenedione were isolated from the media. The percentage conversion of progesterone to $11 \beta$-hydroxyandrostenedione was higher than the percentage conversion of this precursor into androstenedione. The data demonstrate that less than one per cent (uncorrected for manipulative losses) of progesterone$16-\mathrm{H}^{3}$ was converted to the $\mathrm{C}-19$ steroids measured.

The "normal," hyperplastic, and adenomatous tissues released approximately the same amount of androgen in the presence of progesterone compared to similar incubations without this substrate (Tables II, III). In contrast, incubation of $17 \alpha^{-}$ hydroxypregnenolone- $7 \alpha-\mathrm{H}^{3}$ with adenomatous and hyperplastic slices resulted in conversion of 6 and 7 per cent of the substrate to androstenedione and $11 \beta$-hydroxyandrostenedione, respectively (Table VII). In addition, 1.6 and 1.4 per cent of this substrate was converted to tritium-labeled dehydroepiandrosterone. There was a slight decrease in the specific activity (SA) between dehydroepiandrosterone, androstenedione, and $11 \beta$-hydroxyandrostenedione with the adenomatous slices of M.C. On the other hand, the SA of the androgens synthesized by the hyperplastic slices of P.P. are of the same order of magnitude, 14.3, 12.5, and 13.0 $\mu \mathrm{c}$ per $\mu$ mole (Table VII).
Since these experiments suggested that $17 \alpha$-hydroxypregnenolone alone appeared to be a better substrate than progesterone for adult adrenal androgen biosynthesis, an incubation of hyperplastic adrenal slices was carried out with a mixture of tritium-labeled $17 \alpha$-hydroxypregnenolone and $\mathrm{C}^{14}$ labeled progesterone. Ten units of ACTH per gram of slices was added to alternate flasks. In Table VIII the results of this study are listed. The percentage conversion of tritium-labeled $17 \alpha^{-}$ hydroxypregnenolone to androstenedione and $11 \beta$ hydroxyandrostenedione greatly exceeded that of $\mathrm{C}^{14}$-labeled progesterone. The percentage conversion of the $17 \alpha$-hydroxypregnenolone to dehydroepiandrosterone was about the same (2.1) as the values observed in previous incubations with $17 \alpha$ hydroxypregnenolone, 1.6 and 1.4 per cent (Table VII).

The low percentage conversion of $17 \alpha$-hydroxypregnenolone to dehydroepiandrosterone compared to androstenedione and $11 \beta$-hydroxyandrostenedione (Tables VII and VIII) prompted a study of the $3 \beta$-ol dehydrogenase system (and double-bond shifting from $\Delta^{5}$ to $\Delta^{4}$ ) in fresh hyperplastic adrenal slices. The $\Delta^{5}-3 \beta$-ol substrate dehydroepiandrosterone was readily converted to the $\Delta^{4}$-3-ketone androgens androstenedione and $11 \beta$-hydroxyandrostenedione as shown in Table IX.

Identification of adrenal androgens from incubations with radioactive substrates. After chemical determinations were performed, the C-19 steroids derived from a common precursor were pooled separately and carrier androstenedione, $11 \beta$-hydroxyandrostenedione, and dehydroepiandrosterone were added. (Carrier dehydroepiandrosterone was not added to paper eluates from the incuba- 
HUMAN ADULT ADRENAL ANDROGENS

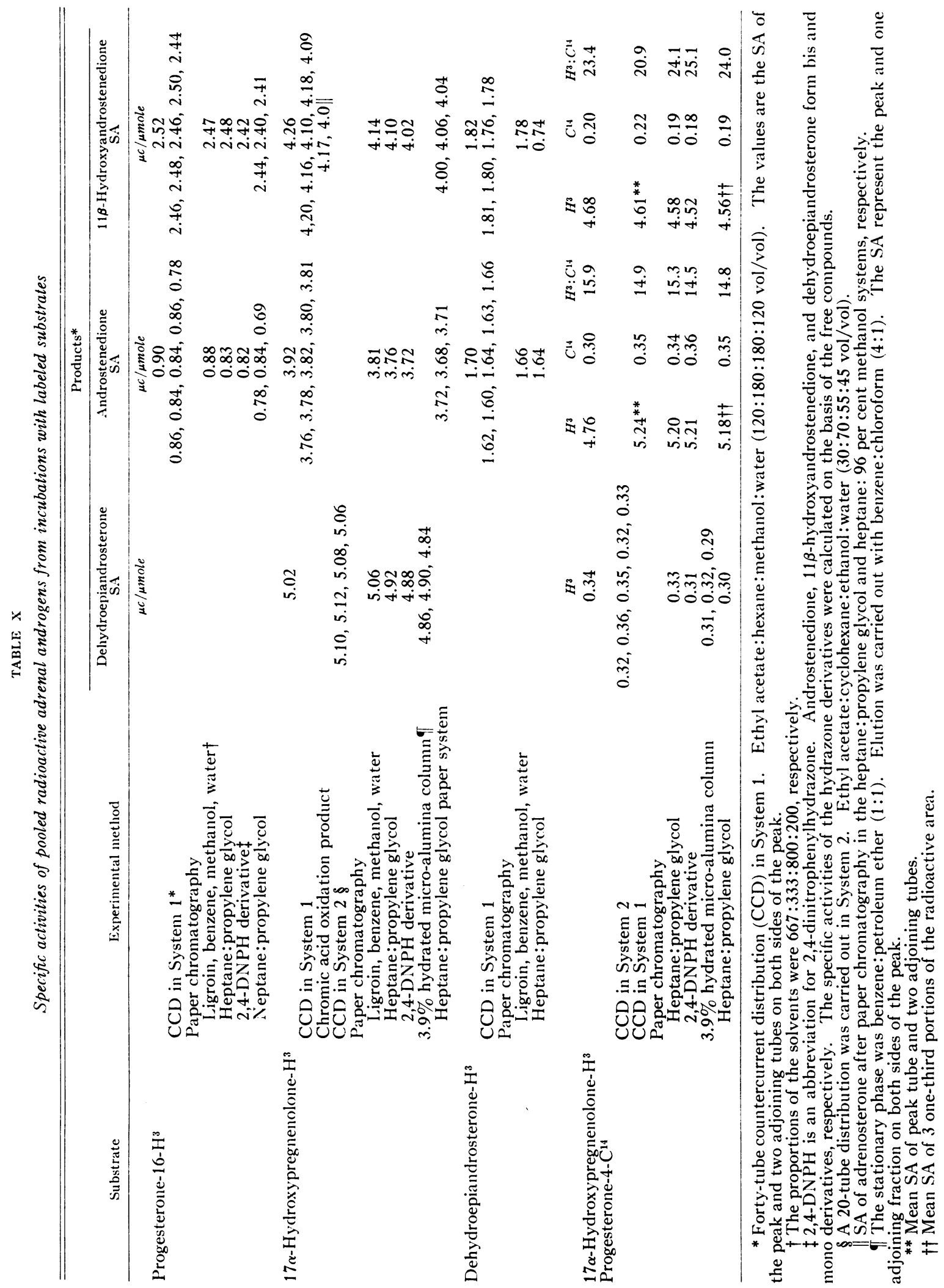


tion experiments with progesterone- $\left.\mathrm{H}^{3}\right) .{ }^{11}$ Identification was verified by identical observed and theoretical distributions of the free androgens in the countercurrent systems and characteristic mobilities in two different paper chromatographic systems. The reported column (dehydroepiandrosterone only) and paper chromatographic mobilities and spectrophotometric spectra of the steroid 2,4-dinitrophenylhydrazone derivatives were observed, further substantiating the identification of the isolated androgens. The SA of the pooled androgens (and carriers) from individual substrate experiments (Tables VI-IX) along with the experimental conditions used for identification are listed in Table X. Constant SA were maintained, indicating radiochemical purity of the measured compounds.

\section{DISCUSSION}

Androgen release by adult human adrenal gland slices. The use of an in vitro incubation technique with human adrenal slices affords a direct approach to an understanding of adrenal androgen metabolism. The data from the present incubations (Tables II-IV) indicate that the slices 1) release detectable amounts of free androgens, dehydroepiandrosterone, androstenedione, and $11 \beta$ hydroxyandrostenedione into the media and 2) respond to adrenocorticotropin (ACTH) in vitro.

In the present study the amounts of dehydroepiandrosterone and androstenedione released per gland per three hours in vitro are less than the quantities found by Hirschmann, deCourcy, Levy, and Miller (17) in the adrenal vein blood of two patients with breast carcinoma and one patient with essential hypertension. In contrast, the adrenal venous blood levels of $11 \beta$-hydroxyandrostenedione are of the same order of magnitude found by the in vitro tissue slice method (Table II). There is also a marked discrepancy between the low dehydroepiandrosterone levels determined by the in vitro technique (and analysis of adrenal vein blood) (17) compared to the normal in vivo secretory rates of this $\mathrm{C}-19$ steroid (15 to $25 \mathrm{mg}$

\footnotetext{
${ }^{11} \mathrm{In}$ the $17 \alpha$-hydroxypregnenolone- $\mathrm{H}^{3}$ studies, $100 \mu \mathrm{g}$ of carrier testosterone was added to a portion of the overflow from the cyclohexane: dioxane: methanol: water system. After acetylation, the extract was chromatographed in the heptane:propylene glycol system. The isolated testosterone acetate was devoid of radioactivity.
}

per 24 hours) determined by Vande Wiele and Lieberman (18)..$^{12}$

On the other hand, the adrenal tissue from three patients with Cushing's syndrome, L.H., L.J., and M.C. (Table IV) released $11 \beta$-hydroxyandrostenedione, only in the presence of ACTH, commensurate with normal secretory rates of 2.0 mg per 24 hours reported by Bradlow and Gallagher (19). The comparison between the two methods is made on the assumption that the 3 -hour in vitro release rate projected to 24 hours is constant over that interval. The data of Cooper and associates (3) substantiate the validity of this speculation for C-21 steroids and $11 \beta$-hydroxyandrostenedione.

The stimulatory effect of ACTH on $11 \beta$-hydroxyandrostenedione production in vitro (Table III) is in agreement with the data of Dyrenfurth, Lucis, Beck, and Venning (6); Touchstone, Glazer, Cooper, and Roberts (46) ; and Cooper and associates (3), despite the differences of glandular weights and pathological findings of the adrenal tissues. The most striking increase of $11 \beta$-hydroxyandrostenedione production occurred with ACTH in the atrophic glands of L.J. and M.C. (Table II), resulting in 8- and 34-fold increases, respectively. The functional capacity of these two tissues is demonstrated also by the effect of ACTH on dehydroepiandrosterone and androstenedione production. There is a slight rise of the androstenedione level in both tissues. However, the elevated (control) dehydroepiandrosterone in J.C. fell with ACTH, 14.3 to $5.3 \mu \mathrm{g}$ per $\mathrm{g}$ per 3 hours, and rose in L.J. from a control value of 0 to $4.4 \mu \mathrm{g}$ per $\mathrm{g}$ per 3 hours. The effect of $\mathrm{ACTH}$ on dehydroepiandrosterone release is ambiguous with other glands from patients with Cushing's syndrome. The failure to detect testosterone in the incubation media implies that this steroid is not usually one of the adrenal androgens produced.

Adrenal androgen biosynthesis. The studies demonstrate the conversion of radioactive steroid

12 Recent observations (47) by the authors indicate that human adrenal tissues form dehydroepiandrosterone sulfate from $17 \alpha$-hydroxypregnenolone and dehydroepiandrosterone. It is certain that our extraction procedures would not remove steroid sulfates from the media, which may possibly explain the low observed unconjugated dehydroepiandrosterone values. 


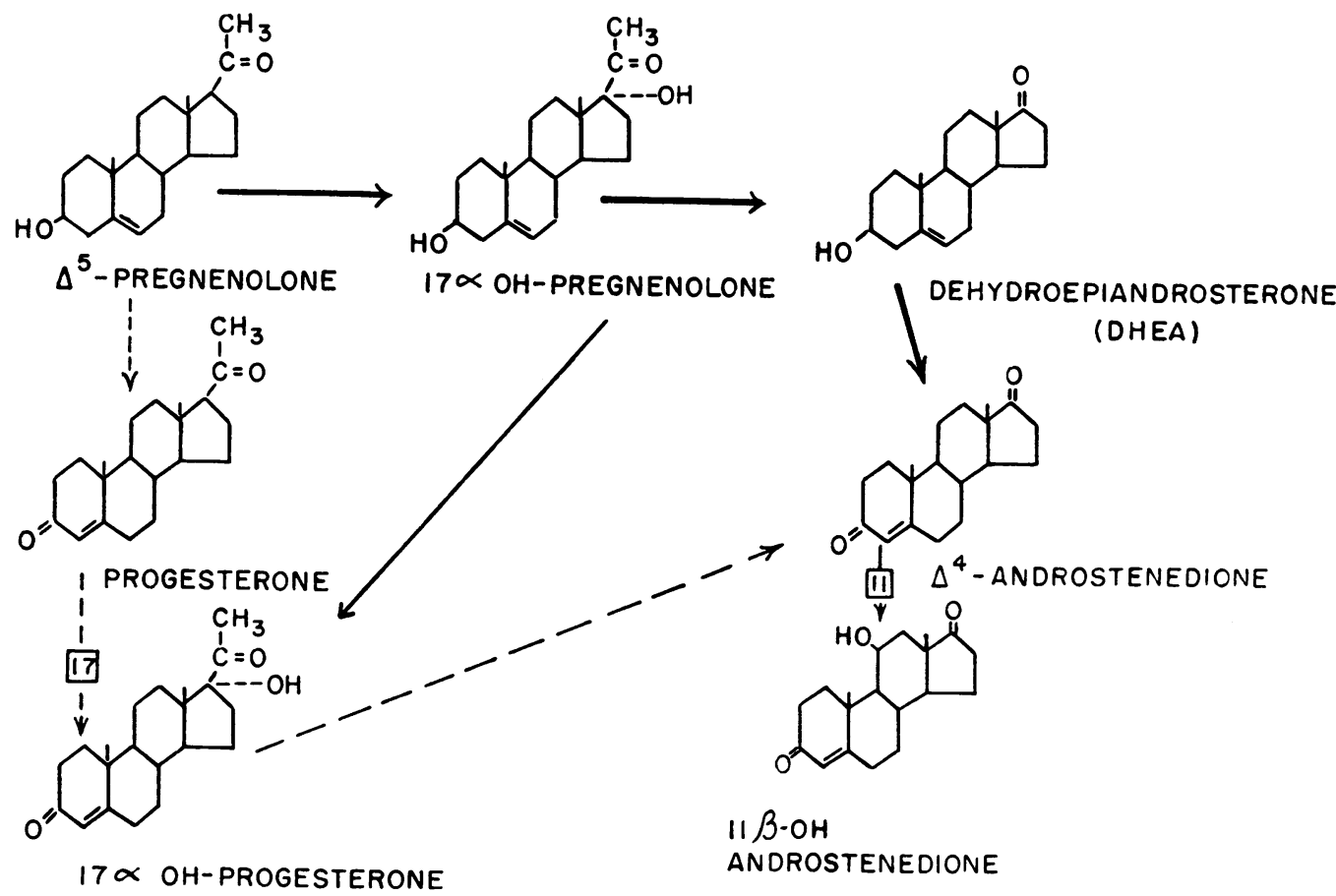

Fig. 2. Pathways of adult adrenal androgen biosynthesis. The solid line indicates the major pathway in the present study.

substrates to C-19 steroids with "normal," hyperplastic, and adenomatous tissue slices. The data from Tables VI to IX suggest the probable biosynthetic sequence of androgen production shown in Figure 2.

The biosynthesis of dehydroepiandrosterone from $17 \alpha$-hydroxypregnenolone with adenomatous and hyperplastic adrenal slices (Table VII) confirms previous observations of Lipsett and Hökfelt (24). Their results, however, seem to indicate that $17 \alpha$-hydroxypregnenolone is not the important "intra-adrenal" precursor of dehydroepiandrosterone in the "normal" adrenal gland slice. The in vitro data in Table VII and VIII show that adrenal tissues from three patients with Cushing's syndrome are capable of this conversion, substantiating in vivo observations of this pathway in a patient with metastatic adrenal carcinoma (48). ${ }^{13}$ Although this pathway is now well documented, an alternative pathway from cholesterol to dehy-

${ }^{13}$ Recently, Roberts, Vande Wiele, and Lieberman (49) demonstrated that only 0.5 per cent of $17 \alpha$-hydroxypregnenolone was converted to dehydroepiandrosterone in a patient with a virilizing adrenal adenoma, strongly suggesting the adrenal rather than peripheral origin of this androgen. droepiandrosterone not involving $\mathrm{C}-21$ intermediates, pregnenolone and $17 \alpha$-hydroxypregnenolone, has been suggested by Dorfman (50).

The formation of dehydroepiandrosterone from pregnenolone and $17 \alpha$-hydroxypregnenolone is closely associated with the hypothesis that androstenedione may arise from these steroids via an alternative pathway without the intermediate progesterone (Figure 2 ). Since a $3 \beta$-ol dehydrogenase system and double-bond shift are required for the conversion of the $\Delta^{5}-3 \beta$-ol steroids to the corresponding $\Delta^{4}$-3-one derivatives $(51,52)$, studies were designed to investigate this hypothesis. The data in Tables VI to VIII indicate that adult adrenal tissues convert a higher percentage of the $\Delta^{5}$-3 $\beta$-ol substrate, $17 \alpha$-hydroxypregnenolone, than the $\Delta^{4}$-3-one precursor, progesterone, to the product androstenedione. A common intermediate to both these reactions may be $17 \alpha$-hydroxyprogesterone as seen in Figure 2. Also, $17 \alpha-$ hydroxypregnenolone can be converted to androstenedione via dehydroepiandrosterone. Villee, Engel, Loring, and Villee observed that fresh human fetal adrenal tissues formed androstenedione from progesterone $4-\mathrm{C}^{14}$ early in gesta- 
tion but not after 12 to 15 weeks gestational age (53). These investigators suggested the 21-hydroxylation appeared to reach a maximum at 12 to 15 weeks gestation with concomitant diminished 17-hydroxylation and disappearance of androstenedione. These findings are opposite to those of Solomon, Lanman, Lind, and Lieberman, who described $17 \alpha$-hydroxyprogesterone and androstenedione conversion from progesterone-4- $\mathrm{C}^{14}$ with frozen fetal adrenal tissues of 10 to 22 weeks gestation (25). Differences in co-factor additions (Solomon added diphosphopyridine nucleotide and adenosine triphosphate and Villee, triphosphopyridine nucleotide and glucose 6-phosphate) and the status of the tissues may account for the differences of the results. Although $17 \alpha$-hydroxyprogesterone is present in normal and hyperplastic adult adrenal tissues $(7,28)$, the factors regulating subsequent 21-hydroxylation of $17 \alpha$-hydroxyprogesterone to 11-deoxycortisol (Compound S) compared to side-chain cleavage to androstenedione may determine the predominant direction of the pathway. When a mixture of tritium-labeled $17 \alpha-$ hydroxypregnenolone and $\mathrm{C}^{14}$-labeled progesterone are incubated with hyperplastic adrenal slices of A.D. (Cushing's syndrome, Table VIII), the $\mathrm{H}^{3}: \mathrm{C}^{14}$ ratios of androstenedione $(15.8: 1)$ compared to cortisol $(1.3: 1)$ (28) are observed. The high $\mathrm{H}^{3}: \mathrm{C}^{14}$ in androstenedione, despite the fact that much less androstenedione was produced compared to cortisol, suggests that the major proportion of this androgen and $11 \beta$-hydroxyandrostenedione are probably derived via a pathway which does not utilize progesterone, presumably by way of $17 \alpha$-hydroxypregnenolone $\rightarrow$ DHEA $\rightarrow$ androstenedione $\rightarrow 11 \beta$-hydroxyandrostenedione. However, further studies are necessary to determine the significance of $17 \alpha$-hydroxyprogesterone as an intermediate for adrenal androgen biosynthesis.

In addition, the high $\mathrm{H}^{3}: \mathrm{C}^{14}$ ratio of $11 \beta$-hydroxyandrostenedione $(22: 1)$ compared to cortisol (28) implies that "intra-adrenal" side-chain cleavage of cortisol is an unlikely pathway for $11 \beta$ hydroxyandrostenedione formation. The data indicate that 11-hydroxylation of androstenedione is the more plausible explanation for the biosynthesis of $11 \beta$-hydroxyandrostenedione in the tissues studied.
The results of substrate conversions with adrenal slice incubations must be interpreted with reservation. Tissue membrane permeability, availability of intracellular co-factors, endogenous pools of steroid intermediates and products, and enzymatic activity are limiting factors not controlled by the tissue slice method. Further studies are thus necessary with purified human adrenal enzyme preparations to elucidate the conditions which regulate the pathways of pregnenolone metabolism to the corticosteroids, or androgens, or both.

\section{SUMMARY}

These studies demonstrate that fresh human adult "normal," atrophic, "hypertensive," hyperplastic, adenomatous, and carcinomatous tissue slices release dehydroepiandrosterone, androstenedione, and 11 $\beta$-hydroxyandrostenedione into the media after three hours of incubation in KrebsRinger bicarbonate buffer, fortified with glucose. The addition of ACTH to the system increases $11 \beta$-hydroxyandrostenedione release in all tissues. ACTH did not stimulate dehydroepiandrosterone and androstenedione release.

In addition, data are presented for the pathways of adrenal androgen synthesis in "normal," hyperplastic, and adenomatous tissues. The data suggest that adrenal androgens are converted predominantly from $17 \alpha$-hydroxypregnenolone $\rightarrow$ dehydroepiandrosterone $\rightarrow$ androstenedione $\rightarrow 11 \beta$ hydroxyandrostenedione rather than from progesterone $\rightarrow$ androstenedione $\rightarrow 11 \beta$-hydroxyandrostenedione.

\section{ACKNOWLEDGMENT}

The authors wish to express their appreciation to $\mathrm{Mr}$. Albert Kuljian, Mr. Walter Hirniak, Miss Eleanor Laime, and Miss Vera Dunne for technical assistance.

\section{REFERENCES}

1. Berliner, M. L., Berliner, D. L., and Dougherty, T. F. Metabolism of progesterone by adrenal tissue from patients with Cushing's syndrome and mammary carcinoma. J. clin. Endocr. 1958, 18, 109.

2. Davignon, J., Koiw, E., Nowaaczynski, W., Tremblay, G., and Genest, J. Studies on the in vitro production of corticosteroids by adrenal glands from normotensive individuals and hypertensive patients. Canad. J. Biochem. 1962, 40, 285. 
3. Cooper, D. Y., Touchstone, J. C., Roberts, J. M., Blakemore, W. S., and Rosenthal, O. Steroid formation by adrenal tissue from hypertensives. J. clin. Invest. 1958, 37, 1524.

4. Bongiovanni, A. M. In vitro hydroxylation of steroids by whole adrenal homogenates of beef, normal man, and patients with adrenogenital syndrome. J. clin. Invest. 1958, 37, 1342.

5. Bailey, E. E., Slade, C. I., Lieberman, A. H., and Luetscher, J. A., Jr. Steroid production by human adrenal adenomata and nontumorous adrenal tissue in vitro. J. clin. Endocr. 1960, 20, 457.

6. Dyrenfurth, I., Lucis, O. J., Beck, J. C., and Venning, E. H. Studies in patients with adrenocortical hyperfunction. III. In iitro secretion of steroids by human adrenal glands. J. clin. Endocr. 1960, 20, 765 .

7. Lombardo, M. E., and Hudson, P. B. The biosynthesis of adrenocortical hormones by the human adrenal gland in vitro. Endocrinology 1959, $65,417$.

8. Grant, J. K., Symington, T., Duguid, W. P. Effect of adrenocorticotrophic therapy on the in vitro $11 \beta$-hydroxylation of desoxycorticosterone by human adrenal homogenates. J. clin. Endocr. 1957, $17,933$.

9. Mulrow, P. J., and Cohn, G. L. Conversion of corticosterone-4- $\mathrm{C}^{14}$ to aldosterone by human adrenal slices. Proc. Soc. exp. Biol. (N. Y.) 1959, 101, 731.

10. Ayres, P. J., Eichhorn, J., Hechter, O., Soba, N., Tait, J. F., and Tait, S. A. S. Some studies on the biosynthesis of aldosterone and other adrenal steroids. Acta endocr. (Kbh.) 1960, 33, 27.

11. Mulrow, P. J., and Cohn, G. L. Corticosteroid release and synthesis in vitro by adrenal slices from patients with Cushing's syndrome. J. clin. Invest. 1961, 40, 1250.

12. Plantin, L. O., Diczfalusy, E., and Birke, G. Isolation of dehydroepiandrosterone from an adrenal cortical tumour. Nature (Lond.) 1957, 179, 421.

13. Anliker, R., Rohr, O., and Marti, M. Untersuchungen über Organextrakte. Utber den Nachweis von Testosteron in einem virilsierenden Nebennierenrindentumor. Helv. chim. Acta 1956, 39, 1100.

14. Romanoff, E. B., Hudson, P., and Pincus, G. Isolation of hydrocortisone and corticosterone from human adrenal vein blood. J. clin. Endocr. 1953, 13, 1546.

15. Bush, I. E., and Mahesh, V. B. Adrenocortical hyperfunction with sudden onset of hirsutism. J. Endocr. 1959, 18, 1.

16. Lombardo, M. E., McMorris, C., and Hudson, P. B. The isolation of steroidal substances from human adrenal vein blood. Endocrinology 1959, 65, 426.

17. Hirschmann, H., DeCourcy, C., Levy, R. P., and Miller, K. L. Adrenal precursors of urinary 17 ketosteroids. J. biol. Chem. 1960, 235, PC 48.
18. Vande Wiele, R., and Lieberman, S. The metabolism of dehydroepiandrosterone in Biological Activities of Steroids in Relation to Cancer, G. Pincus and E. P. Vollmer, Eds. New York, Academic Press, 1960, p. 93.

19. Bradlow, H. L., and Gallagher, T. F. Metabolism of $11 \beta$-hydroxy- $\Delta^{4}$-androstene-3,17-dione in man. J. biol. Chem. 1957, 229, 505.

20. Migeon, C. J. Androgens in human plasma in Hormones in Human Plasma, H. N. Antoniades, Ed. Boston, Little, Brown, 1960, p. 297.

21. Engel, L. L., and Langer, L. J. Biochemistry of steroid hormones in Annual Review of Biochemistry, J. M. Luck, Ed. Palo Alto, Annual Reviews, 1961, vol. 30, p. 499.

22. Bloch, E., Dorfman, R. I., and Pincus, G. The conversion of acetate to $C_{19}$ steroids by human adrenal gland slices. J. biol. Chem. 1957, 224, 737.

23. Goldstein, M., Gut, M., Dorfman, R. I. Conversion of pregnenolone to dehydroepiandrosterone. Biochim. biophys. Acta (Amst.) 1960, 38, 190.

24. Lipsett, M. B., and Hökfelt, B. Conversion of $17 \alpha-$ hydroxypregnenolone to cortisol. Experientia (Basel) 1961, 17, 449.

25. Solomon, S., Lanman, J. T., Lind, J., and Lieberman, S. The biosynthesis of $\Delta^{4}$-androstenedione and $17 \alpha-$ hydroxyprogesterone from progesterone by surviving human fetal adrenals. J. biol. Chem. 1958, 233, 1084.

26. Bloch, E., and Benirschke, K. Synthesis in vitro of steroids by human fetal adrenal gland slices. J. biol. Chem. 1959, 234, 1085.

27. Mulrow, P. J., Cohn, G. L., and Kuljian, A. Conversion of 17-hydroxypregnenolone to cortisol by normal and hyperplastic human adrenal slices. J. clin. Invest. 1962, 41, 1584.

28. Hayes, M. A., and Goldenberg, I. S. Operative treatment of adrenal cortical hyperfunctioning diseases (suppl.). Ann. Surg. 1961, 154, 33.

29. Norymberski, J. K. Determination of urinary corticosteroids. Nature (Lond.) 1952, 170, 1074.

30. Lakshmanan, T. K., and Lieberman, S. An improved method of gradient elution chromatography and its application to the separation of urinary ketosteroids. Arch. Biochem. 1954, 53, 528.

31. Jailer, J. W., Vande Wiele, R., Christy, N. P., and Lieberman, S. Studies in Cushing's syndrome. III. Urinary 17 -ketosteroids in patients with bilateral adrenal cortical hyperplasia. J. clin. Invest. 1959, 38, 357.

32. Philip, B. A., Cohn, G. L., and Bondy, P. K. Cortisol secretion rates and intermediary metabolism in normal volunteers and in patients with adrenal dysfunction. Trans. Ass. Amer. Phycns 1961, 74, 163.

33. Bush, I. E. Methods of paper chromatography of steroids applicable to the study of steroids in mammalian blood and tissues. Biochem. J. 1952, 50, 370. 
34. Kliman, B., and Peterson, R. E. Double isotope derivative assay of aldosterone in biological extracts. J. biol. Chem. 1960, 235, 1639.

35. Carstensen, H., and Oertel, G. N., Eik-Nes, K. B. Secretion of $17 \alpha$-hydroxy- $\Delta^{5}$-pregnenolone by the canine adrenal gland during stimulation with adrenocorticotropin. J. biol. Chem. 1959, 234, 2570.

36. Cohn, G. L., Bondy, P. K., and Castiglione, C. Studies on pyrogenic steroids. I. Separation, identification, and measurement of unconjugated dehydroepiandrosterone, etiocholanolone, and androsterone in human plasma. J. clin. Invest. 1961, 40, 400.

37. Bush, I. E. and Willoughby, M. The excretion of allotetrahydrocortisol in human urine. Biochem. J. 1957, 67, 689.

38. Burton, R. B., Zaffaroni, A., and Keutmann, E. H. Paper chromatography of steroids. II. Corticosteroids and related compounds. J. biol. Chem. 1951, 188, 763.

39. Abelson, D., and Bondy, P. K. Fluorometric determination of $\Delta^{4}$-3-ketosteroids. Arch. Biochem. 1955, 57, 208.

40. Bondy, P. K., Abelson, D., Scheuer, J., Tseu, T. K. L., and Upton, V. Determination of cortisol in human plasma by quantitative paper chromatography. J. biol. Chem. 1957, 224, 47.

41. Rubin, B. L., Dorfman, R. I., and Pincus, G. A method for the quantitative analysis of 17-ketosteroid mixtures. J. biol. Chem. 1953, 203, 629.

42. Migeon, C. J., and Plager, J. E. Neutral 17-ketosteroids in human plasma in Recent Progress in Hormone Research, G. Pincus, Ed. New York, Academic Press, 1954, vol. 9, p. 235.

43. Way, E. L., and Bennett, B. M. Rapid estimation of theoretical counter-current distribution values. J. biol. Chem. 1951, 192, 335.

44. Savard, K., Dorfman, R. I., Baggett, B., Fielding, L. L., Engel, L. L., McPherson, H. T., Lister, L. M., Johnson, D. S., Hamblen, E. C., and Engel, F. L. Clinical, morphological and biochemical studies of a virilizing tumor in the testis. J. clin. Invest. 1960, 39, 534.

45. Lieberman, S., Katzenellenbogen, E. R., Schneider, R., Studer, P. E., and Dobriner, K. Isolation of urinary steroids after cortisone and adrenocorticotropic hormone. J. biol. Chem. 1953, 205, 87.

46. Touchstone, J. C., Glazer, L., Cooper, D. Y., and Roberts, J. M. The isolation of $\Delta^{4}$-androstene-11 $\beta$ ol-3,17-dione from human adrenal incubates. J. clin. Endocr. 1955, 15, 382.

47. Cohn, G. L., Mulrow, P. J., and Dunne, V. C. The in vitro synthesis of dehydroepiandrosterone-sulfate by an adrenal adenoma in The Program of the Forty-Fourth Meeting of the Endocrine Society, June, 1962, p. 48.

48. Solomon, S., Carter, A. C., and Lieberman, S. The conversion in vivo of 17- $\alpha$-hydroxypregnenolone to dehydroisoandrosterone and other 17 -ketosteroids. J. biol. Chem. 1960, 235, 351.

49. Roberts, K. D., Vande Wiele, R. L., Lieberman, S. $17 \alpha$-Hydroxypregnenolone as a precursor of urinary steroids in a patient with a virilizing adenoma of the adrenal. J. clin. Endocr. 1961, 21, 1522.

50. Dorfman, R. I. A system for evaluating the functional status of the adrenal cortex. Metabolism 1961, 10, 902.

51. Samuels, L. T. Studies of the enzymes involved in the synthesis and degradation of the hormones of the adrenal cortex in Ciba Foundation Colloquium on Endocr., W. Klyne, G. E. W. Wolstenholme, and M. P. Cameron, Eds. Boston, Little, Brown, 1953, vol. 7, p. 176.

52. Rubin, B. L., Leipsner, G., Deane, H. W. A rapid, sensitive assay procedure for adrenal steroid-3 $\beta$-oldehydrogenase activity. Endocrinology 1961, 69, 619.

53. Villee, D. B., Engel, L. L., Loring, J. M., and Villee, C. A. Steroid hydroxylation in human fetal adrenals : formation of $16 \alpha$-hydroxyprogesterone, 17-hydroxyprogesterone, and deoxycorticosterone. Endocrinology 1961, 69, 354. 